Jurnal Pemberdayaan: Publikasi Hasil Pengabdian kepada Masyarakat

Vol. 2, No. 1, April 2018, Hal. 35-43

ISSN: 2088 4559; e-ISSN: XXXX-XXXX

DOI:

\title{
PROGRAM HIDUP SEHAT MASYARAKAT PEDUKUHAN SALAM, BANJARHARJO KALIBAWANG
}

\author{
Dewi Eko Wati ${ }^{1}$, Tiyah Pungky ${ }^{2}$, Farhan Arsyahdi ${ }^{3}$, Siska Trianingsih ${ }^{4}$ \\ Universitas Ahmad Dahlan Yogyakarta ${ }^{1,2,3,4}$ \\ dewi.ekowati@pgpaud.uad.ac.id
}

\begin{abstract}
ABSTRAK
Salah satu permasalahan yang ada di masyarakat Desa Banjarharjo, Kecamatan Kalibawang, Kabupaten Kulon Progo, Yogyakarta adalah kurangnya keterampilan masyarakat dalam memanfaatkan sampah yang masih dapat dimanfaatkan. Maka program KKN UAD difokuskan pada Pola Hidup Bersih dan Sehat (PHBS). Program ini bertujuan memberdayakan masyarakat Pedukuhan Salam dalam program hidup sehat. Metode pelaksanaan program KKN meliputi: pendidikan masyarakat, difusi iptek dan praktik. Dampak dari kegiatan KKN ini adalah 1) tercipta kesadaran masayarakat sasaran tentang pentingnya Pola Hidup Bersih dan Sehat (PHBS); 2) peningkatan pengetahuan masyarakat dalam mengolah sampah; dan 3) masyarakat dapat memanfaatkan botol bekas menjadi perangkap lalat.
\end{abstract}

Kata kunci: pedukuhan Salam, hidup sehat, pemanfaatan sampah.

\begin{abstract}
One of the problems in the community of Banjarharjo Village, Kalibawang District, Kulon Progo Regency, Yogyakarta is the lack of community skills in utilizing waste that can still be utilized. Then the UAD KKN program is focused on a Clean and Healthy Lifestyle (PHBS). This program aims to empower the Salam Hamlet community in a healthy life program. The methods for implementing the KKN program include: community education, science and technology diffusion and practice. The impact of this KKN activity is 1) creating awareness of the target community about the importance of a Clean and Healthy Lifestyle (PHBS); 2) increasing public knowledge in processing waste; and 3) the community can take advantage of empty bottles into a trap flies.
\end{abstract}

Keyword: Hamlet Salam, Healthy lifestyle, utilization of garbage

\section{PENDAHULUAN}

Desa Banjarharjo merupakan salah satu desa budaya dari 32 desa budaya sesuai dengan Keputusan Gubernur no 325/KPTS/1995 tanggal 24 November 1995. Desa budaya Banjarharjo terletak di Kecamatan Kalibawang, Kulon Progo dengan batas sebelah selatan dan barat yaitu, Desa Banjarasri dan sebelah utara Desa Banjaroya. Desa Banjarharjo juga berbatasan langsung dengan wilayah Kabupaten Magelang, Provinsi Jawa Tengah, dan Kabupaten Sleman, D.I.Yogyakarta di sebelah timur. Desa Banjarharjo dialiri dua aliran sungai, yaitu Sungai Krawang dan Sungai Klepu yang alirannya masih alami dengan satu 
saluran irigasi yang mengalir sejajar. Desa Banjarharjo adalah salah satu dari sepuluh desa di Kabupaten Kulon Progo yang ditetapkan sebagai desa budaya. Status desa budaya dimiliki Desa Banjarharjo karena potensi budayanya. Potensi budaya yang menjadi aset budaya lokal memuat ide-ide, tradisi, nilai-nilai kultural dan perilaku dalam kehidupan masyarakat setempat.

Desa Banjarharjo memiliki 22 pedukuhan salah satunya Pedukuhan Salam yang memiliki 6 RT dan 3 RW. Akses jalan di Pedukuhan Salam cukup mudah dilalui oleh kendaraan darat baik roda dua maupun roda empat. Keadaan tanah di Desa Banjarharjo sangat subur dan air cukup memadai dari aliran Sungai Progo. Dengan kondisi tanah yang subur masyarakat Desa Banjarharjo memiliki kegiatan bercocok tanam dan sebagian besar masyarakat Desa Banjarharjo bekerja sebagai petani. Selain itu, kondisi perairan yang terdapat di Desa Banjarharjo juga dapat membantu kegiatan sehari-hari masyarakat dan pembenihan ikan lele.

Beberapa masalah yang ditemukan di Desa Banjarharjo adalah: 1) kurangnya pengetahuan masyarakat terkait pengolahan sampah;2) kurangnya keterampilan masyarakat dalam memanfaatkan sampah yang masih dapat dimanfaatkan; dan 3) kurangnya kesadaran masyarakat akan pentingnya hidup sehat.

Peran serta masyarakat dalam hidup sehat merupakan kesediaan masyarakat untuk membantu berhasilnya program perilaku hidup sehat sesuai dengan kebijakan pemerintah. Tanpa adanya peran serta masyarakat semua program perilaku hidup sehat tidak akan terlaksana sesuai dengan rencana. Salah satu pendekatan masyarakat untuk dapat membantu program pemerintah dalam keberhasilan adalah dengan membiasakan masyarakat berperilaku hidup sehat yang sesuai dengan program Pola Hidup Bersih dan Sehat (PHBS) yaitu upaya untuk memberikan pengalaman belajar atau menciptakan suatu kondisi bagi perorangan, keluarga, kelompok, dan masyarakat, dengan membuka jalur komunikasi, memberikan informasi dan melakukan edukasi untuk meningkatkan pengetahuan sikap dan perilaku, melalui advokasi, sosial support dan pemberdayaan masyarakat. Dengan demikian masyarakat dapat mengenali dan mengatasi masalahnya sendiri terutama dalam tatanan masing-masing, dan masyarakat dapat menerapkan cara-cara hidup sehat dengan menjaga, memelihara, dan meningkatkan kesehatannya. Ada tiga faktor yaitu, (1) faktor predisposisi: pengetahuan, sikap, kepercayaan, keyakinan, nilai-nilai, dsb; (2) faktor enabling: lingkungan fisik, tersedia atau tidak tersedianya fasilitas atau sarana-sarana kesehatan; dan (3) faktor 
reinforcing: perilaku petugas kesehatan atau petugas lain yang merupakan kelompok referensi dari perilaku masyarakat (Green dalam Debora.dkk. 2016).

Demam Berdarah Dengue (DBD) adalah penyakit yang disebabkan oleh infeksi virus Dengue yang ditularkan melalui gigitan nyamuk Aedes Aegypti yang ditandai dengan demam mendadak, sakit kepala, nyeri belakang, bola mata, dan mual (Kemenkes: 2016). Berdasarkan pengertian yang diungkapkan oleh Kementerian Kesehatan, penyebaran virus terjadi karena gigitan nyamuk. Dengan begitu, penyebaran dan bahkan penyebabnya dapat ditanggulangi dengan adanya gerakan 3M. Selain itu, penanggulangan bisa dengan dibentuknya jumantik untuk setiap rumah. Pembentukan jumantik ini disasarkan pada anak-anak usia sekolah dasar yang ada di Desa Banjarharjo. Jumantik sendiri adalah orang yang melakukan pemeriksaan, pemantauan, dan pemberantasan jentik nyamuk khususnya Aedes Aegypti dan Aedes Albopicus (Kemenkes: 2016). Pelaksanaan pembentukan jumantik ini disasarkan pada anakanak sehingga memunculkan para jumantik cilik di lingkungan Desa Banjarharjo. Seperti namanya, jumantik cilik dimaksudkan agar anak-anak mampu melakukan pemeriksaan, pemantauan, dan pemberantasan jentik di rumah masing-masing.

Pentingnya jumantik di setiap rumah agar menjadi pengendali vektor DBD. Dengan adanya pengendali di setiap rumah, kemungkinan berkembangnya jentik menjadi nyamuk dapat diperkecil. Dengan begitu DBD dapat diberantas bahkan dikendalikan sehingga tercipta lingkungan sehat yang terbebas dari DBD. Pengendalian vektor DBD yang digunakan dalam program ini adalah pengendalian secara fisik. Pengendalian fisik merupakan alternative utama pengendalian vektor DBD melalui upaya pemberantasan sarang nyamuk (PSN) dengan cara menutup, menguras, dan mengubur/mendaur ulang (3M) (Kemenkes: 2013). Cara ini akan memberikan efek yang baik jika dilakukan secara berkesinambungan.

Tangan adalah salah satu penghantar utama masuknya kuman penyakit ketubuh manusia. Mencuci tangan adalah proses yang secara mekanis melepaskan kotoran dan debris tersebut dari kulit tangan dengan menggunakan sabun biasa dan air yang mengalir (Depkes RI, 2007). Kegiatan mencuci tangan ini meliputi pembersihan bagian telapak tangan, punggung tangan, jaridan kuku jari. Tujuannya agar bersih dari kotoran dan membunuh kuman penyebab penyakit yang dapat merugikan kesehatan. Cuci tangan dengan sabun dapat menghambat masuknya kuman penyakit ketubuh manusia. Kuman penyakit seperti virus dan bakteri tidak dapat terlihat secara kasat mata sehingga sering diabaikan dan mudah masuk ketubuh manusia (Wati, 2011). 
Berdasarkan permasalah tersebut maka ditetapkan tujuan program $\mathrm{KKN}$ ini adalah memberdayakan masyarakat Desa Banjarharjo dalam program hidup sehat.

\section{METODE}

Untuk mencapai tujuan yang diharapkan, progam KKN di Desa Banjarharjo dilakukan dengan pemberdayaan masyarakat melalui pendidikan masyarakat, difusi ilmu pengetahuan dan teknologi dan praktek langsung. Ringkasan metode pelaksanaan beserta jam kerja efektif mahasiswa (JKEM) tersaji pada tabel 1:

Tabel 1. Metode, Kegiatan, JKEM dan Keterlibatan Mahasiswa

\begin{tabular}{|c|c|c|c|c|}
\hline No & Metode & Kegiatan & JKEM & $\begin{array}{c}\text { Jumlah } \\
\text { Mahasiswa } \\
\text { yang } \\
\text { Terlibat }\end{array}$ \\
\hline \multirow[t]{5}{*}{1} & $\begin{array}{l}\text { Pendidikan } \\
\text { Masyarakat }\end{array}$ & $\begin{array}{l}\text { Menyelenggarakan penyuluhan dan } \\
\text { praktik PHBS tentang cuci tangan }\end{array}$ & $5 \times 2 \mathrm{Jam}$ & 9 \\
\hline & & $\begin{array}{l}\text { Menyelenggarakan penyuluhan PHBS } \\
\text { tentang tidak merokok di dalam } \\
\text { ruangan }\end{array}$ & $1 \times 2 \mathrm{Jam}$ & 1 \\
\hline & & $\begin{array}{l}\text { Menyelenggarakan penyuluhan } \\
\text { kesehatan }\end{array}$ & $4 \times 1 \mathrm{Jam}$ & 11 \\
\hline & & $\begin{array}{l}\text { Menyelenggarakan } \\
\text { jumantik cilik }\end{array}$ & $2 \times 1 \mathrm{Jam}$ & 2 \\
\hline & & $\begin{array}{l}\text { Menyelenggarakan penyuluhan kode } \\
\text { plastik }\end{array}$ & $2 \times 1 \mathrm{Jam}$ & 3 \\
\hline 2 & $\begin{array}{l}\text { Difusi } \\
\text { Iptek }\end{array}$ & $\begin{array}{l}\text { Menyelenggarakan } \\
\text { pembuatan kompos }\end{array}$ & $2 \times 3 \mathrm{Jam}$ & 9 \\
\hline \multirow[t]{3}{*}{3} & Praktek & $\begin{array}{l}\text { Pelatihan pembuatan perangkap lalat } \\
\text { dari botol plastik }\end{array}$ & $1 \times 3$ Jam & 1 \\
\hline & & $\begin{array}{l}\text { Pelatihan pembuatan kerajinan tangan } \\
\text { dari koran }\end{array}$ & $1 \times 3 J a m$ & 3 \\
\hline & & $\begin{array}{l}\text { Pelatihan pembuatan tempat sampah } \\
\text { dari ember cat }\end{array}$ & $3 \times 3 \mathrm{Jam}$ & 9 \\
\hline
\end{tabular}

\section{HASIL, PEMBAHASAN, DAN DAMPAK}

\section{A. Profil Desa}

Desa Banjarharjo merupakan salah satu desa yang ada di Kecamatan Kalibawang, Kabupaten Kulon Progo. Wilayah Desa Banjarharjo ini mempunyai batas wilayah sebelah selatan dan barat yaitu, Desa Banjarasri dan sebelah utara Desa Banjaroya.Desa 
Banjarharjo juga berbatasan langsung dengan wilayah Kabupaten Magelang, Provinsi Jawa Tengah, dan Kabupaten Sleman, D.I.Yogyakarta di sebelah timur.

Luas Desa Banjarharjo adalah 1234,56 ha. Wilayah Desa Banjarharjo terdiri dari $70 \%$ wilayah perbukitan dengan hasil bumi dominan berupa durian, cengkeh, buah naga, dan buah manggis. Pusat Desa Banjarharjo berjarak $35 \mathrm{Km}$ arah utara Ibukota Kabupaten Kulon Progo, kemudian Wates yang dapat diakses sekitar 30-40 menit dengan jalur darat melalui jalan provinsi dengan pusat pemerintahan $2 \mathrm{Km}$ di sebelah selatan Ibukota Kecamatan di jalan Sentolo-Muntilan Km 20 Kalibawang. Terdapat juga makan Pahlawan Nasional yang terkenal yaitu Pahlawan Nasional Nyi Ageng Serang yang merupakan salah satu Panglima Perang serta ahli taktik dan siasat perang gerilya Pangeran Diponegoro.

Komposisi penduduk Desa Banjarharjo berdasarkan usia dan presentasenya dapat dilihat pada gambar 1 .

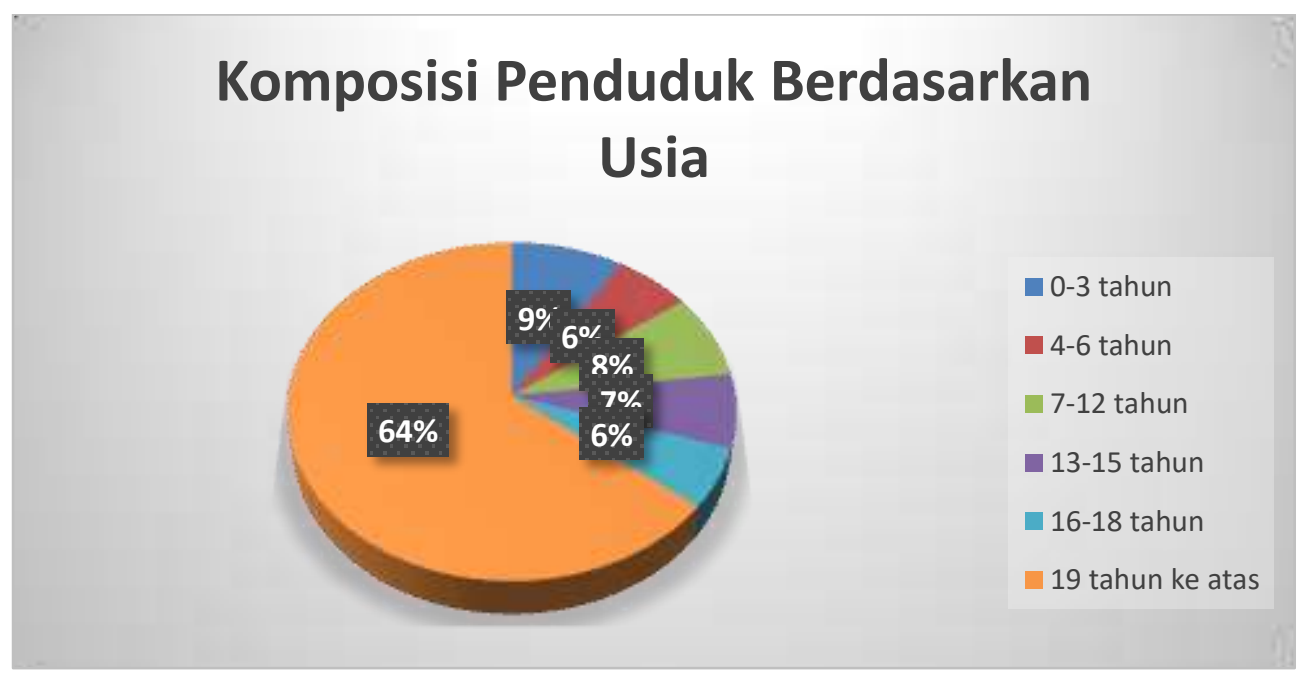

Gambar 1. Komposisi Penduduk Berdasarkan Usia

Komposisi penduduk berdasarkan usia yaitu, usia 0-3 tahun sebesar 9\%, usia 4-6 tahun sebesar 6\%, usia 7-12 tahun sebesar 8\%, usia 13-15 tahun sebesar 7\%, usia 16-18 tahun sebesar 6\%, dan usia 19 tahun ke atas sebesar 64\%. Komposisi penduduk berdasarkan tingkat pendidikan dapat dilihat dalam gambar 2.

Komposisi penduduk Desa Banjarharjo berdasarkan pendidikan dan presentasenya dapat dilihat pada gambar 2 . 


\section{Jumlah Penduduk Berdasarkan Tingkat Pendidikan}

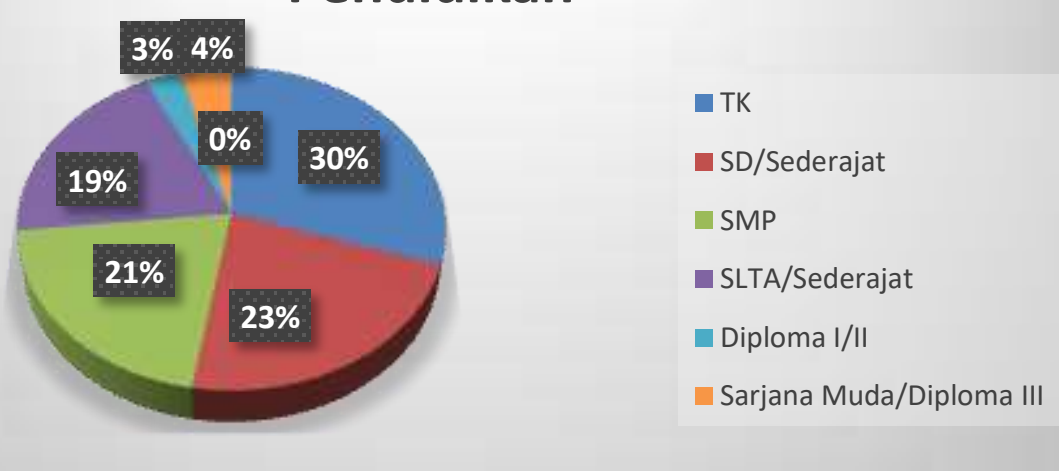

Gambar 2. Komposisi Penduduk Berdasarkan Tingkat Pendidikan

Komposisi penduduk berdasarkan tingkat pendidikan yaitu, TK sebesar 30\%, SD/Sederajat sebesar 23\%, SMP sebesar 21\%, SLTA/Sederajat sebesar 19\%, Diploma I/II sebesar 3\%, dan Sarjana Muda/Diploma II sebesar 4\%. Komposisi penduduk berdasarkan mata pencaharaian dapat dilihat di gambar 3.

Komposisi penduduk Desa Banjarharjo berdasarkan mata pencaharian dan presentasenya dapat dilihat pada gambar 3.

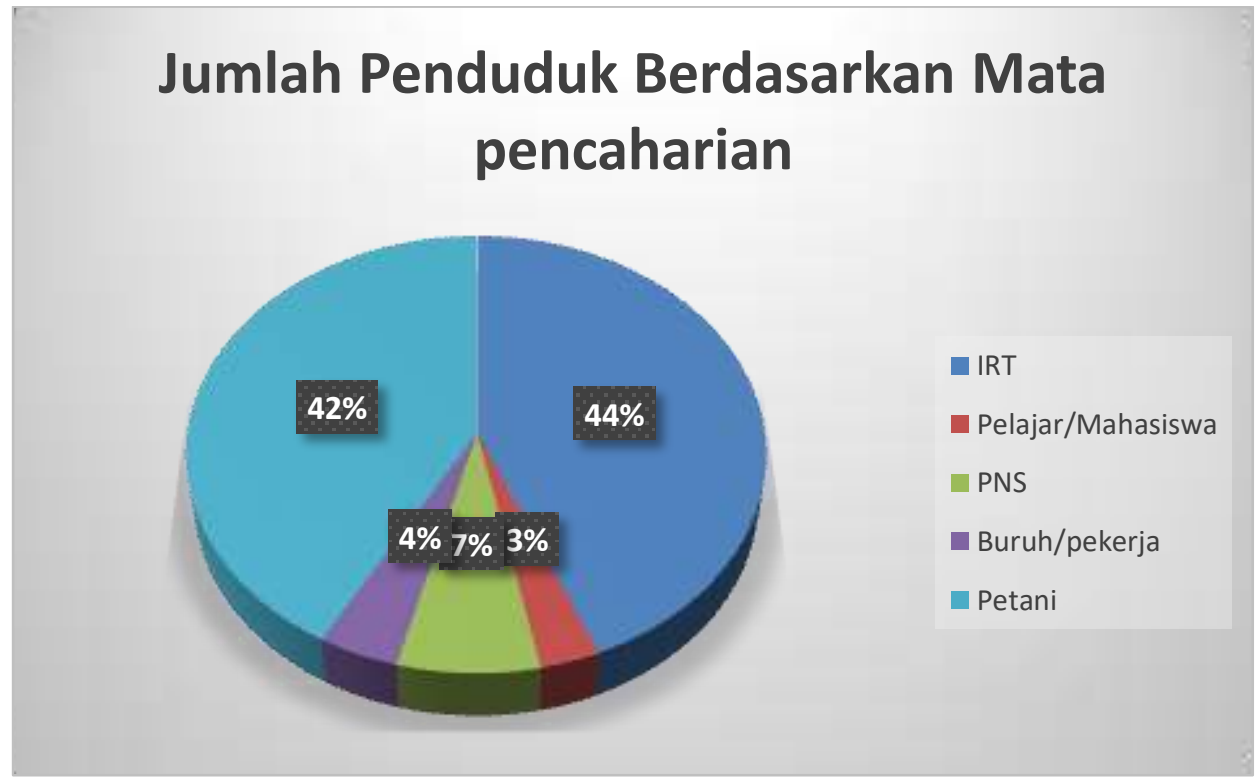

Gambar 3. Komposisi Penduduk Berdasarkan Mata Pencaharian

Komposisi penduduk berdasarkan mata pencaharian yaitu, mata pencaharian sebagai IRT sebesar 44\%, sebagai pelajar/mahasiswa sebesar 3\%, sebagai PNS sebesar 7\%, sebagai Buruh/pekerja sebesar 4\%, dan sebagai petani $42 \%$. 


\section{B. Gambaran Pelaksanaan}

Gambar aktivitas mahasiswa KKN UAD dan masyarakat Desa Banjarharjo dalam program perilaku hidup sehat tersaji pada gambar 4 .

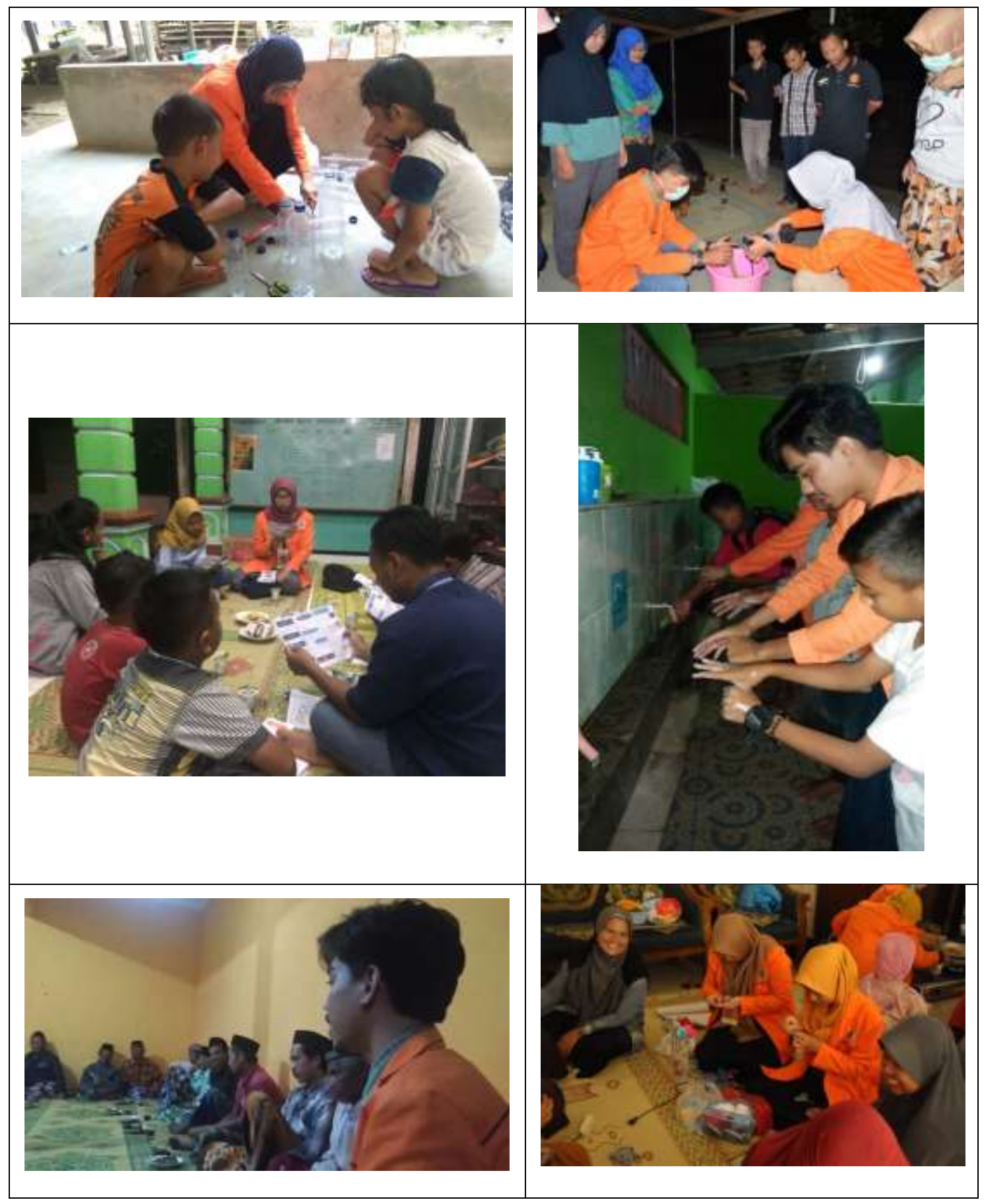




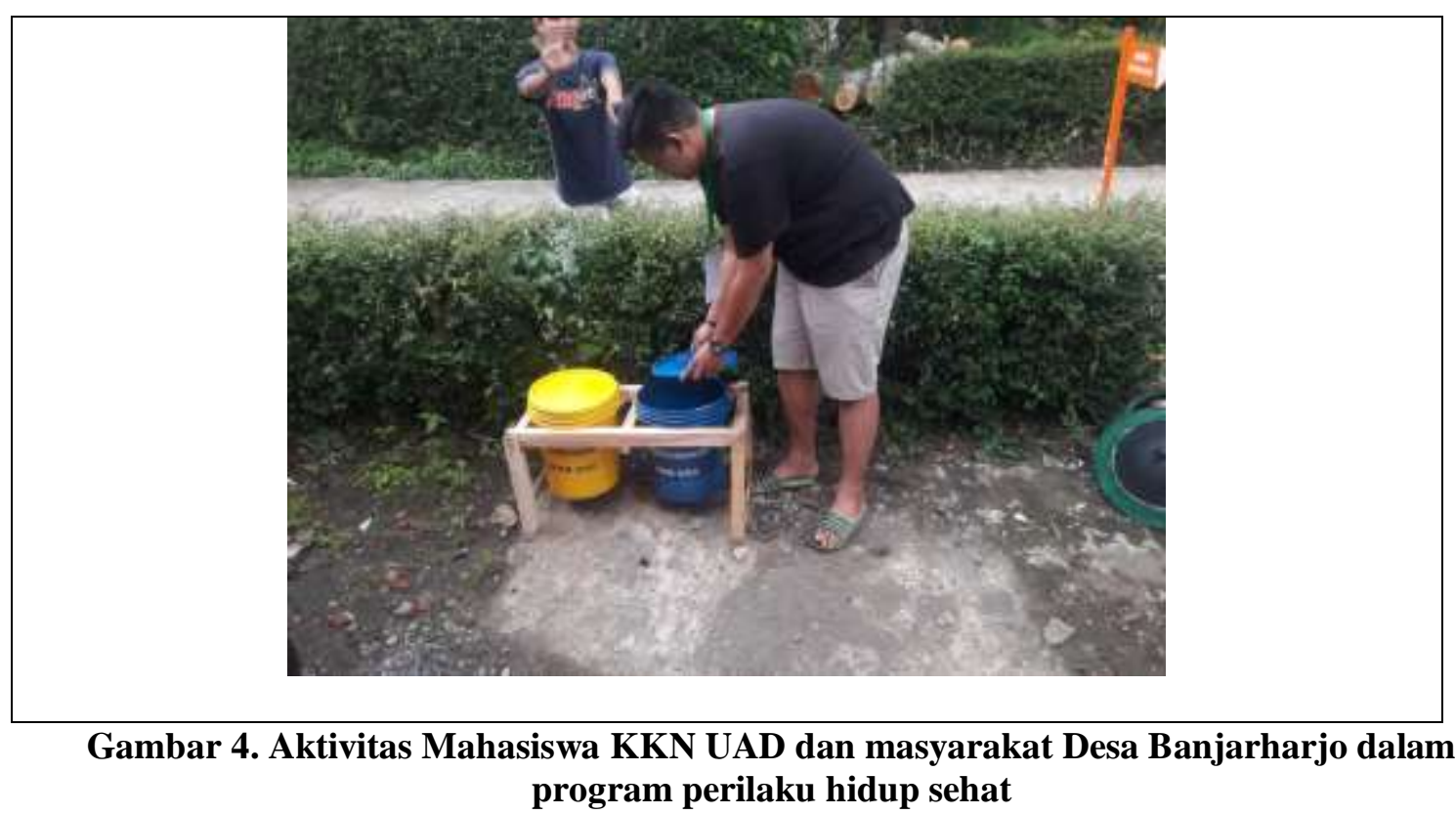

Dari gambar 4 terlihat program KKN di Desa Banjarharjo dapat terlaksana dengan partisipasi masyarakat yang baik. Dengan kata lain dapat memperdayakan masyarakat dalam program-program yang telah direncanakan. Dampak dari kegiatan KKN ini adalah: 1) tercipta kesadaran masayarakat sasaran tentang pentingnya Pola Hidup Bersih dan Sehat (PHBS); 2) peningkatan pengetahuan masyarakat dalam mengolah sampah; dan 3) masyarakat dapat memanfaatkan botol bekas menjadi perangkap lalat.

\section{SIMPULAN}

Program KKN dengan tema program hidup sehat masyarakat pedukuhan salam, banjarharjo kalibawang berjalan dengan lancar. Masyarakat terlihat antusias mengikuti kegiatan yang diselenggrakan oleh mahasiswa. Program ini mampu meningkatkan kesadaran masyarakat tentang pentingnya pola hidup sehat, meningkatkan pengetahuan masyarakat tentang cara pengelolaan sampah, dan memanfaatkan barang bekas menjadi sesuatu yang berguna yaitu botol bekas menjadi perangkap lalat.

\section{DAFTAR PUSTAKA}

Depkes RI. 2007.Profil Kesehatan Indonesia. Jakarta

Kementerian Kesehatan Republik Indonesia. 2013. Pedoman Pengendalian Demam Berdarah Dengue di Indonesia. Jakarta: Kementerian Kesehatan Republik Indonesia. 


\section{Jurnal Pemberdayaan: Publikasi Hasil Pengabdian kepada Masyarakat - ISSN: 2088 4559; e-ISSN:}

Kementerian Kesehatan Republik Indonesia. 2016. Petunjuk Teknis Implementasi PSN 3MPLUS dengan Gerakan 1 Rumah 1 Jumantik. Jakarta: Kementerian Kesehatan Republik Indonesia.

Siahaan, Debora.dkk. 2016. Jurnal Kesehatan Masyarakat “Faktor-faktor yang Berhubungan dengan Pelaksanaan Perilaku Hidup Bersih dan Sehat oleh Guru UKS Sekolah Dasar di Kecamatan Banyumanik Kota Semarang”. Vol. 4 nomor 5.

Wati, R. 2011. Pengaruh Pemberian Penyuluhan PHBS Tentang Mencuci Tangan Terhadap Pengetahuan dan Sikap Mencuci Tangan Pada Siswa Kelas V di SDN Bulukantil Surakarta. Skripsi. Kebidanan UNS. Surakarta.

\section{UCAPAN TERIMAKASIH}

1. Dr. Widodo, M.Si sebagai Kepala LPPM Universitas Ahmad Dahlan beserta staff yang telah memberikan kesempatan untuk menjadi DPL KKN.

2. Mahasiswa KKN regular periode 65 khususnya unit $\mathrm{C}$ kelurahan Banjarharjo kecamatan Kalibawang 